\title{
Natural Surfactant Combined with Beclomethasone Decreases Lung Inflammation in the Preterm Lamb
}

\author{
Carlo Dani $^{\mathrm{a}}$ luri Corsini ${ }^{\mathrm{a}} \quad$ Silvia Burchielli $^{\mathrm{b}}$ Valentina Cangiamila ${ }^{\mathrm{c}}$ \\ Roberta Romagnolid Bhattacharjee Jayonta ${ }^{d}$ Mariangela Longini ${ }^{e}$ \\ Ferdinando Paternostro ${ }^{f}$ Giuseppe Buonocore ${ }^{b}$
}

a Section of Neonatology, Department of Surgical and Medical Critical Care, Careggi University Hospital of Florence, Florence, ${ }^{b}$ Institute of Clinical Physiology, Consiglio Nazionale delle Ricerche, and ${ }^{\mathrm{c}}$ Faculty of Veterinary,

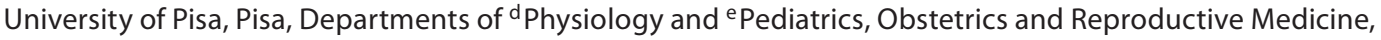
University of Siena, Siena, and f Department of Anatomy, Histology, and Forensic Medicine, University of Florence, Florence, Italy

\section{Key Words}

Surfactant $\cdot$ Beclomethasone $\cdot$ Glucocorticoid •

Inflammation • Lung injury $\cdot$ Preterm lamb

\begin{abstract}
Background: Natural surfactant combined with beclomethasone decreases pulmonary oxidative stress in preterm lambs with respiratory distress syndrome (RDS). Objectives: To test the hypothesis that this occurs through a decrease in pulmonary inflammation. Methods: Preterm lambs received $200 \mathrm{mg} / \mathrm{kg}$ of natural surfactant or $200 \mathrm{mg} / \mathrm{kg}$ of natural surfactant combined with 400 or $800 \mu \mathrm{g} / \mathrm{kg}$ of beclomethasone. Interleukin 8 (IL-8) and macrophage migration inhibitory factor (MIF) were assayed in bronchial aspirate samples and lung mechanics were evaluated. Results: IL-8 increased in all the groups, but the increase was lower in the groups treated with surfactant plus 400 and $800 \mu \mathrm{g} / \mathrm{kg}$ of beclomethasone. MIF decreased in the surfactant group, did not vary in the surfactant plus $400 \mu \mathrm{g} / \mathrm{kg}$ beclomethasone group, and decreased in the surfactant plus $800 \mu \mathrm{g} / \mathrm{kg}$ beclomethasone group. MIF concentration was higher in the
\end{abstract}

surfactant plus $800 \mu \mathrm{g} / \mathrm{kg}$ beclomethasone group than in the other groups. Conclusions: Natural surfactant combined with beclomethasone at $800 \mu \mathrm{g} / \mathrm{kg}$ is effective in reducing lung inflammation in an animal model of RDS, thus explaining the associated decrease in lung oxidative stress. The increase in MIF in animals treated with surfactant plus $800 \mu \mathrm{g} /$ $\mathrm{kg}$ of beclomethasone might be an important maturative and protective factor for neonatal lungs.

Copyright $\odot 2011$ S. Karger AG, Basel

\section{Introduction}

Preterm infants are frequently affected by lung disorders such as respiratory distress syndrome (RDS) and bronchopulmonary dysplasia (BPD). Although the etiology of these pathologies is multifactorial, the pathogenetic role of inflammatory injuries to lung tissues has been well documented $[1,2]$. Several authors have demonstrated that RDS and mechanical ventilation with oxygen are associated with increased recruitment of inflammatory cells within lung tissues $[3,4]$, as favored by an

\section{KARGER}

Fax +4161306 1234

E-Mail karger@karger.ch

www.karger.com
(C) $2011 \mathrm{~S}$. Karger AG, Basel

$0025-7931 / 11 / 0824-0369 \$ 38.00 / 0$

Accessible online at:

www.karger.com/res
Carlo Dani, MD

Division of Neonatology, Careggi University Hospital

University of Florence School of Medicine

Viale Morgagni, 85, IT-50141 Firenze (Italy)

Tel. +39055 7947 428, E-Mail cdani@unifi.it 
increase in pulmonary microvascular permeability and chemotactic activity [3]. Also, neutrophils activated by cytokines and other mediators produce oxygen radicals which damage the lung by increasing collagenase activity, disrupting the extracellular matrix, and inducing the typical fibrotic process of BPD $[5,6]$.

It has been demonstrated that natural surfactant can modulate the pulmonary inflammatory cascade by inhibiting macrophage-mediated neutrophil chemotaxis [7], nitric oxide production [8], oxidative burst activity [9], and secretion of proinflammatory cytokines from alveolar macrophages [10]. In addition, glucocorticoids have been shown to decrease oxidative stress in lungs in the presence of inflammation [11-14]. Thus, one main effect of postnatal steroids in preventing or improving BPD is probably mediated through a decrease in oxidative stress via a reduction in the inflammatory response [15]. Moreover, direct intratracheal administration of a steroid using surfactant as a vehicle could permit us to overcome the inadequacy of aerosol delivery systems and prevent the side effects of systemic steroids. In fact, we recently demonstrated that treatment with natural surfactant combined with beclomethasone in preterm lambs with RDS decreases pulmonary oxidative stress and neutrophil count in the bronchoalveolar lavage fluid of treated animals [16]. To explain this result, we hypothesized that beclomethasone added to surfactant exerts its antioxidant effect at least partially through decreased neutrophil activity and lung inflammation. However, we did not measure cytokine concentration changes, and thus this speculation remains unproven.

Therefore, the hypothesis of this study was that the pulmonary antioxidant effects of surfactant plus beclomethasone are associated with downregulation of lung inflammation. To test this hypothesis, we evaluated cytokine changes in the bronchial aspirate fluid of preterm lambs that were randomized to receive natural surfactant plus beclomethasone or only a natural surfactant. We chose beclomethasone because it is cheap and its effectiveness is similar to that of other inhaled steroids [17]. Moreover, we decided to measure interleukin 6 (IL-6) and 8 (IL-8) and the macrophage migration inhibitory factor (MIF) because: (1) IL-6 is a proinflammatory cytokine which plays a relevant role in the pathogenesis of BPD in preterm infants [18]; (2) IL-8 is probably the most important chemotactic factor [18] in the human immune system; (3) MIF has recently been found to play a key role in pulmonary maturation and protection in newborn lung disease $[19,20]$.

\section{Materials and Methods}

The experimental protocol was designed in compliance with the recommendations of the European Economic Community (86/609/CEE) for the care and use of laboratory animals and was approved by the Animal Care Committee of the University of Florence.

\section{Animals and Instrumentation}

The study design has been described previously [16]. Briefly, animals were delivered by cesarean section at $124 \pm 1.7$ days of gestational age from Massa ewes (term 145 days of gestational age) and then instrumented to assist and monitor vital functions. Before the first breath, the lambs received randomly $200 \mathrm{mg} / \mathrm{kg}$ of natural porcine surfactant (Curosurf ${ }^{\circledR}$; Chiesi SpA, Parma, Italy), followed by $10 \mathrm{ml}$ air given into the airways with a syringe, or 200 $\mathrm{mg} / \mathrm{kg}$ of natural surfactant combined with 400 or $800 \mu \mathrm{g} / \mathrm{kg}$ of beclomethasone dipropionate (Clenil $\mathrm{A}^{\circledR}$; Chiesi SpA). Randomization was performed before delivery using the closed-envelope method.

All animals were ventilated for $6 \mathrm{~h}$ with time-cycled and pressure-limited infant ventilators (Newport Breeze Ventilator; Soma Technology Inc., Bloomfield, Conn., USA) using similar ventilation strategies.

The initial ventilator settings included positive end-expiratory pressure: $4 \mathrm{~cm} \mathrm{H}_{2} \mathrm{O}$ and a peak inspiratory pressure sufficient to obtain a target tidal volume $\left(\mathrm{V}_{\mathrm{T}}\right)$ of about $10 \mathrm{ml} / \mathrm{kg}$. The fraction of inspired oxygen was adjusted to maintain a target $\mathrm{pO}_{2}(100-150$ $\mathrm{mm} \mathrm{Hg}$ ). The individuals responsible for ventilator adjustments were masked to the treatment assignment. Blood gas, $\mathrm{pH}$, and base excess were analyzed by a blood gas, electrolyte, and metabolite system (Radiometer Copenhagen USA, West Lake, Ohio, USA) and recorded as soon as possible after delivery, and $1\left(\mathrm{~T}_{1}\right)$, $2\left(\mathrm{~T}_{2}\right), 4\left(\mathrm{~T}_{4}\right)$, and $6\left(\mathrm{~T}_{6}\right) \mathrm{h}$ after surfactant administration.

\section{Lung Mechanics Monitoring}

Mean airway pressure (MAP), dynamic lung compliance $\left(C_{d y n}\right)$, exhaled $V_{T}$, and expiratory resistance $\left(R_{a w}\right)$ were measured with a neonatal respiratory monitor (Florian Neonatal Respiration Monitor ${ }^{\mathrm{TM}}$; Acutronic, Hirzel, Switzerland), and their values at baseline, $\mathrm{T}_{1}, \mathrm{~T}_{2}, \mathrm{~T}_{4}$, and $\mathrm{T}_{6}$ were recorded.

\section{Experimental Procedures}

Bronchial aspirate samples from animals were obtained with the following technique: $1 \mathrm{ml} / \mathrm{kg}$ sterile $0.9 \%$ saline was instilled using a 10 -ml syringe through an eight-french gauge feeding catheter that had been placed in the endotracheal tube so that the tip extended $1 \mathrm{~cm}$ beyond the distal end of the tube. The saline was instilled and immediately aspirated back into the syringe. The mean volume of saline returned was $0.8 \pm 0.2 \mathrm{ml} / \mathrm{kg}$.

All samples were clarified by centrifugation $(1,000 \mathrm{rpm} \times$ $5 \mathrm{~min}$ ) and the supernatant was immediately frozen at $-70^{\circ} \mathrm{C}$ and stored for subsequent analysis. Bronchial aspirate samples were collected from each animal before surfactant administration, after exposure of the fetal head, and at $\mathrm{T}_{1}, \mathrm{~T}_{2}, \mathrm{~T}_{4}$, and $\mathrm{T}_{6} \mathrm{~h}$ after surfactant administration.

\section{Tissue Removal and Pathologic Examination}

At the end of the experiment, the animals were killed with an overdose of pentobarbital, tissue was removed and pathological 
examination was performed. The left lung was instilled with saline at $4^{\circ} \mathrm{C}$, and the aspirate was then washed in and out of the lungs 3 times and then recovered to obtain bronchoalveolar lavage fluid. This washing procedure was repeated 5 times for each animal, with the 5 washes finally being pooled and the total volume recorded. Total cell counts were measured in uncentrifuged alveolar lavage fluid using a hemacytometer counting chamber. Differential cell counts were performed on cytocentrifuge preparations by using standard morphologic criteria for macrophages, neutrophils and lymphocytes. The trachea and lungs were placed into a buffered $10 \%$ formalin bath. Two random pulmonary specimens were obtained from the upper and lower lobes of both lungs for histology. Routine techniques were used to prepare the tissues for paraffin embedding. Five-micrometer-thick sections were stained with hematoxylin-eosin and two pathologists performed the blinded microscopic examination. Terminal airway distension was graded 0 when the terminal airways were similar to those of the control lungs, 1 when they were dilated (between 1-1.5 times the control airway caliber), and 2 when they were markedly dilated (more than 1.5 times the control airway caliber). In addition, the following histological features were analyzed: areas of atelectasis, interstitial and/or alveolar edema, inflammatory infiltration, interlobular septum ruptures, and desquamation of bronchiolar epithelium. Each pathological feature was evaluated as 1 when present and 0 when absent. Pulmonary damage was obtained by adding up the score on each pathological feature and was graded as follows: negative $=0$, slight $=0-1$, moderate $=2-3$, and severe $\geq 4[16]$.

\section{Cytokine Assays}

We measured IL-6, IL-8, and MIF in each bronchial aspirate sample. For IL- 8 and IL- 6 determination, plates were coated with $100 \mu \mathrm{l}$ of anti-ovine IL- 6 or IL- 8 monoclonal antibody $(5 \mu \mathrm{g} / \mathrm{ml})$ (Millipore, Billerica, Mass., USA) and incubated overnight at room temperature. The plates were washed 3 times with buffer [ 10 mM PBS (pH 7.4), 0.05\% (v/v) Tween 20], blocked by adding 300 $\mu \mathrm{l}$ of blocking solution [10 mM PBS ( $\mathrm{pH} 7.4$ ), $1 \%$ (wt/v) bovine serum albumin], and incubated at room temperature for $1.5 \mathrm{~h}$. The standard ovine recombinant IL- 6 or IL-8 (Moredun Research Institutes, Edinburgh, UK), and pure samples were added in duplicate $(100 \mu \mathrm{l} / \mathrm{w})$ and incubated for $1 \mathrm{~h}$ at room temperature. After 3 washes, $100 \mu$ l of rabbit anti-ovine IL- 6 or IL- 8 polyclonal antibody (1:500) (Millipore) were added to each well and incubated for $30 \mathrm{~min}$ at room temperature. After 3 more washes, anti-rabbit IgG conjugated with horseradish peroxidase $(1: 10,000)$ was added $(100 \mu \mathrm{l} / \mathrm{w})$ and incubated for $30 \mathrm{~min}$. The plates were washed and 3,3',5,5'-tetramethylbenzidine (Zymed Laboratories, San Francisco, Calif., USA) was added. After $20 \mathrm{~min}$, the reaction was stopped by adding $2 \mathrm{M} \mathrm{H}_{2} \mathrm{SO}_{4}$. The absorbance was measured at $450 \mathrm{~nm}$ using Fluoroskan Ascent FL ${ }^{\mathrm{TM}}$ (Thermo Fisher Scientific, Philadelphia, Pa., USA). The IL- 6 and IL- 8 concentrations were extrapolated from a standard curve obtained by serial dilutions of the bacterially expressed recombinant ovine IL- 6 and IL-8 (Moredun Research Institutes) and expressed as arbitrary units. Intraand interassay coefficients of variation for IL- 6 and IL- 8 measurements were $4.99 \pm 0.87$ and $7.2 \pm 0.69 \%$, and $3.11 \pm 0.97$ and $8.99 \pm 0.49 \%$, respectively.

MIF determination was performed as described by Ietta et al. [21]. Briefly, $100 \mu \mathrm{l} /$ well of anti-human MIF monoclonal antibody $(2.0 \mu \mathrm{g} / \mathrm{ml})$ (R\&D Systems, Abingdon, UK) were used for dish coating and $100 \mu \mathrm{l}$ per well of biotinylated goat anti-human MIF polyclonal antibody (200 ng/ml) (R\&D Systems) for MIF detection. The MIF concentration was calculated by extrapolation from a standard curve (range $25-2,000 \mathrm{pg} / \mathrm{ml}$ ) using bacterially expressed recombinant human MIF (R\&D Systems) and expressed as picograms per milliliter. The sensitivity limit was 18 $\mathrm{pg} / \mathrm{ml}$. Intra- and interassay coefficients of variation were $3.86 \pm$ $0.95 \%$ and $9.14 \pm 0.47 \%$, respectively.

\section{Statistical Analysis}

The time course of the evolution of the various parameters in the different groups was compared using a two-way analysis of variance for repeated measurements and one grouping factor (i.e. 'time' and 'treatment'). Intragroup comparisons were tested with the paired Student $t$ tests as data were normally distributed. Results are expressed as means \pm standard deviation, and a $p$ value $<0.05$ was considered significant.

\section{Results}

Eighteen animals were randomized to receive $200 \mathrm{mg} /$ $\mathrm{kg}$ of natural surfactant $(\mathrm{n}=6), 200 \mathrm{mg} / \mathrm{kg}$ of surfactant plus $400 \mu \mathrm{g} / \mathrm{kg}$ of beclomethasone $(\mathrm{n}=6)$, or $200 \mathrm{mg} / \mathrm{kg}$ of surfactant plus $800 \mu \mathrm{g} / \mathrm{kg}$ of beclomethasone $(\mathrm{n}=6)$.

We observed a significant increase in $\mathrm{pH}$ at $\mathrm{T}_{1}, \mathrm{~T}_{2}, \mathrm{~T}_{4}$, and $\mathrm{T}_{6}$ in comparison with baseline values in all groups; $\mathrm{pCO}_{2}$ did not vary in the surfactant group, but decreased significantly in the surfactant plus beclomethasone groups at $\mathrm{T}_{1}, \mathrm{~T}_{2}, \mathrm{~T}_{4}$, and $\mathrm{T}_{6} ; \mathrm{pO}_{2}$ was similar in the groups at each time; base excess tended to decrease in all groups (table 1).

Table 2 shows changes of MAP, $V_{T}, C_{\text {dyn }}$, and $R_{a w}$. MAP decreased in the group treated with surfactant plus $800 \mu \mathrm{g} / \mathrm{kg}$ of beclomethasone at $\mathrm{T}_{4}$ and $\mathrm{T}_{6}$, and was lower than in the other groups; $\mathrm{V}_{\mathrm{T}}$ was lower at baseline than afterwards in all groups; $\mathrm{C}_{\mathrm{dyn}}$ did not change in any group during the study period; $\mathrm{R}_{\mathrm{aw}}$ decreased from baseline in all groups.

Total cell count and neutrophil count were significantly lower in the bronchoalveolar lavage fluid of animals treated with surfactant plus $800 \mu \mathrm{g} / \mathrm{kg}$ of beclomethasone compared with animals only treated with surfactant. Macrophage, lymphocyte and monocyte counts were similar in the three groups (table 3 ).

The mean pulmonary damage score was lower in the surfactant plus $400 \mu \mathrm{g} / \mathrm{kg}$ of beclomethasone group (1.8 $\pm 0.7)$ and in the surfactant plus $800 \mu \mathrm{g} / \mathrm{kg}$ of beclomethasone group $(1.8 \pm 0.3)$ than in the surfactant group (2.4 \pm 0.6), but the difference was not statistically significant [16]. Figure 1 shows the histological appearance of the lung of a preterm lamb treated with surfactant or with surfactant plus $800 \mu \mathrm{g} / \mathrm{kg}$ of beclomethasone. 
Table 1. Changes of blood gas analysis in preterm lambs treated with surfactant, surfactant plus $400 \mu \mathrm{g} / \mathrm{kg}$ of beclomethasone, or surfactant plus $800 \mu \mathrm{g} / \mathrm{kg}$ of beclomethasone (means \pm SDs)

\begin{tabular}{|c|c|c|c|}
\hline & Surfactant & $\begin{array}{l}\text { Surfactant }+ \\
\text { beclomethasone } \\
400 \mu \mathrm{g}\end{array}$ & $\begin{array}{l}\text { Surfactant }+ \\
\text { beclomethasone } \\
800 \mu \mathrm{g}\end{array}$ \\
\hline \multicolumn{4}{|l|}{$\mathrm{pH}$} \\
\hline Baseline & $6.93 \pm 0.09^{*}$ & $6.90 \pm 0.09^{* *}$ & $7.02 \pm 0.07^{* *}$ \\
\hline $\mathrm{T}_{1}$ & $7.11 \pm 0.25$ & $7.26 \pm 0.16$ & $7.34 \pm 0.11$ \\
\hline $\mathrm{T}_{2}$ & $7.23 \pm 0.21$ & $7.32 \pm 0.17$ & $7.36 \pm 0.05$ \\
\hline $\mathrm{T}_{4}$ & $7.23 \pm 0.18$ & $7.32 \pm 0.09$ & $7.36 \pm 0.08$ \\
\hline $\mathrm{T}_{6}$ & $7.19 \pm 0.17$ & $7.36 \pm 0.09$ & $7.37 \pm 0.10^{\circ}$ \\
\hline \multicolumn{4}{|l|}{$\mathrm{pCO}_{2}$} \\
\hline Baseline & $86 \pm 25$ & $109 \pm 12^{* *}$ & $93 \pm 20^{* * *}$ \\
\hline $\mathrm{T}_{1}$ & $62 \pm 26$ & $49 \pm 26$ & $47 \pm 16$ \\
\hline $\mathrm{T}_{2}$ & $70 \pm 40$ & $46 \pm 18$ & $43 \pm 14$ \\
\hline $\mathrm{T}_{4}$ & $63 \pm 29$ & $50 \pm 13$ & $42 \pm 7$ \\
\hline $\mathrm{T}_{6}$ & $64 \pm 38$ & $47 \pm 17$ & $38 \pm 7$ \\
\hline \multicolumn{4}{|l|}{$\mathrm{pO}_{2}$} \\
\hline Baseline & $96 \pm 113$ & $71 \pm 54$ & $106 \pm 133$ \\
\hline $\mathrm{T}_{1}$ & $150 \pm 158$ & $164 \pm 84$ & $147 \pm 110$ \\
\hline $\mathrm{T}_{2}$ & $160 \pm 165$ & $155 \pm 114$ & $100 \pm 134$ \\
\hline $\mathrm{T}_{4}$ & $147 \pm 132$ & $131 \pm 93$ & $151 \pm 139$ \\
\hline $\mathrm{T}_{6}$ & $134 \pm 177$ & $95 \pm 100$ & $123 \pm 146$ \\
\hline \multicolumn{4}{|l|}{ Base excess } \\
\hline Baseline & $-11.7 \pm 6.7^{\wedge}$ & $-5.5 \pm 6.6$ & $-6.6 \pm 5.6$ \\
\hline $\mathrm{T}_{1}$ & $-6.1 \pm 6.6$ & $-6.8 \pm-6.0$ & $-1,3 \pm 2.1$ \\
\hline $\mathrm{T}_{2}$ & $-4.1 \pm 4.4$ & $-0.32 \pm 5.1$ & $-1.1 \pm 2.9$ \\
\hline $\mathrm{T}_{4}$ & $-3.9 \pm 0.7$ & $-1.6 \pm 1.9^{\wedge \wedge}$ & $-2.1 \pm 3.5$ \\
\hline $\mathrm{T}_{6}$ & $-5.3 \pm 4.7$ & $-2.1 \pm 1.9$ & $-3.4 \pm 4.8$ \\
\hline
\end{tabular}

${ }^{*} \mathrm{p}=0.009$ vs. $\mathrm{T}_{2}, \mathrm{p}=0.004$ vs. $\mathrm{T}_{4}, \mathrm{p}=0.008$ vs. $\mathrm{T}_{6} ;{ }^{* *} \mathrm{p}<0.0001$ vs. $\mathrm{T}_{1}, \mathrm{~T}_{2}, \mathrm{~T}_{4}, \mathrm{~T}_{6} ;{ }^{* * *} \mathrm{p}=0.001$ vs. $\mathrm{T}_{1}, \mathrm{p}<0.0001$ vs. $\mathrm{T}_{2}, \mathrm{~T}_{4} ;{ }^{\circ} \mathrm{p}=$ 0.049 vs. surfactant; ${ }^{\wedge} \mathrm{p}=0.018$ vs. $\mathrm{T}_{4} ;{ }^{\wedge \wedge} \mathrm{p}=0.019$ vs. surfactant.

Table 4 shows changes in IL- 8 and MIF. IL- 8 increased in all the groups, but the increase was significantly lower at $T_{2}, T_{4}$, and $T_{6}$ in the groups treated with surfactant plus 400 and $800 \mu \mathrm{g} / \mathrm{kg}$ of beclomethasone than in the surfactant-only group. IL- 6 was undetectable in the studied samples, probably because the method used was not sensitive enough.

MIF transiently increased at $\mathrm{T}_{2}$ and then gradually declined to become lower than baseline at $\mathrm{T}_{6}$ in the surfactant group. In the surfactant plus $400 \mu \mathrm{g} / \mathrm{kg}$ beclomethasone group, MIF concentration did not vary, while in the surfactant plus $800 \mu \mathrm{g} / \mathrm{kg}$ beclomethasone group, its concentration was higher at $\mathrm{T}_{1}, \mathrm{~T}_{2}, \mathrm{~T}_{4}$, and $\mathrm{T}_{6}$ than at baseline. Moreover, MIF concentration at $\mathrm{T}_{2}, \mathrm{~T}_{4}$, and $\mathrm{T}_{6}$ was higher in the surfactant plus $800 \mu \mathrm{g} / \mathrm{kg}$ beclomethasone group than in the other groups.
Table 2. Changes in MAP, $V_{T}, C_{d y n}$ and $R_{a w}$ in preterm lambs treated with surfactant, surfactant plus $400 \mu \mathrm{g} / \mathrm{kg}$ of beclomethasone, or surfactant plus $800 \mu \mathrm{g} / \mathrm{kg}$ of beclomethasone (means \pm SDs)

\begin{tabular}{|c|c|c|c|}
\hline & Surfactant & $\begin{array}{l}\text { Surfactant }+ \\
\text { beclomethasone } \\
400 \mu \mathrm{g}\end{array}$ & $\begin{array}{l}\text { Surfactant }+ \\
\text { beclomethasone } \\
800 \mu \mathrm{g}\end{array}$ \\
\hline \multicolumn{4}{|c|}{$\mathrm{MAP}, \mathrm{cm} \mathrm{H}_{2} \mathrm{O}$} \\
\hline Baseline & $15.2 \pm 1.0$ & $15.8 \pm 1.2$ & $16.2 \pm 1.3$ \\
\hline $\mathrm{T}_{1}$ & $16.0 \pm 2.3$ & $16.2 \pm 1.7$ & $16.2 \pm 1.6$ \\
\hline $\mathrm{T}_{2}$ & $15.6 \pm 1.9$ & $16.0 \pm 1.7$ & $15.8 \pm 2.6$ \\
\hline $\mathrm{T}_{4}$ & $15.5 \pm 1.3$ & $15.2 \pm 3.2$ & $11.0 \pm 2.3^{*}$ \\
\hline $\mathrm{T}_{6}$ & $15.7 \pm 2.6$ & $15.5 \pm 3.0$ & $11.8 \pm 2.5^{* *}$ \\
\hline \multicolumn{4}{|l|}{$\mathrm{V}_{\mathrm{T}}, \mathrm{ml} / \mathrm{kg}$} \\
\hline Baseline & $3.9 \pm 1.7^{\#}$ & $4.1 \pm 1.0^{\#}$ & $4.1 \pm 1.9^{\#}$ \\
\hline $\mathrm{T}_{1}$ & $11.3 \pm 4.2$ & $11.8 \pm 4.2$ & $11.5 \pm 3.2$ \\
\hline $\mathrm{T}_{2}$ & $10.4 \pm 3.0$ & $11.7 \pm 4.4$ & $11.2 \pm 1.3$ \\
\hline $\mathrm{T}_{4}$ & $10.4 \pm 3.1$ & $12.2 \pm 8.3$ & $11.6 \pm 1$ \\
\hline $\mathrm{T}_{6}$ & $11.3 \pm 4.5$ & $11.9 \pm 2.2$ & $11.4 \pm 2.1$ \\
\hline \multicolumn{4}{|l|}{$\mathrm{C}_{\text {dyn }}, \mathrm{kg}$} \\
\hline Baseline & $0.4 \pm 0.1$ & $0.4 \pm 0.5$ & $0.5 \pm 0.8$ \\
\hline $\mathrm{T}_{1}$ & $0.4 \pm 0.1$ & $0.4 \pm 0.1$ & $0.4 \pm 0.1$ \\
\hline $\mathrm{T}_{2}$ & $0.4 \pm 0.1$ & $0.4 \pm 0.1$ & $0.5 \pm 0.3$ \\
\hline $\mathrm{T}_{4}$ & $0.5 \pm 0.1$ & $0.5 \pm 0.2$ & $0.6 \pm 0.2$ \\
\hline $\mathrm{T}_{6}$ & $0.6 \pm 0.3$ & $0.5 \pm 0.1$ & $0.5 \pm 0.1$ \\
\hline \multicolumn{4}{|l|}{$\mathrm{R}_{\mathrm{aw}}, \mathrm{mbar} / \mathrm{l} / \mathrm{s}$} \\
\hline Baseline & $283 \pm 73^{\wedge}$ & $295 \pm 13^{\wedge \wedge}$ & $308 \pm 13^{\wedge \wedge \wedge}$ \\
\hline $\mathrm{T}_{1}$ & $235 \pm 25$ & $219 \pm 41$ & $248 \pm 47$ \\
\hline $\mathrm{T}_{2}$ & $214 \pm 24$ & $225 \pm 20$ & $237 \pm 43$ \\
\hline $\mathrm{T}_{4}$ & $195 \pm 71$ & $225 \pm 11$ & $208 \pm 13$ \\
\hline $\mathrm{T}_{6}$ & $185 \pm 43$ & $208 \pm 44$ & $231 \pm 41$ \\
\hline
\end{tabular}

${ }^{*} \mathrm{p}<0.0001$ vs. baseline, $\mathrm{p}=0.003$ vs. $\mathrm{T}_{1}, \mathrm{p}=0.022$ vs. $\mathrm{T}_{2}, \mathrm{p}=$ 0.002 vs. surfactant, $\mathrm{p}=0.026$ vs. surfactant + beclomethasone $400 ;{ }^{* *} \mathrm{p}=0.003$ vs. baseline, $\mathrm{p}=0.005$ vs. $\mathrm{T}_{1}, \mathrm{p}=0.022$ vs. $\mathrm{T}_{2}$, $\mathrm{p}=0.024$ vs. surfactant, $\mathrm{p}=0.043$ vs. surfactant + beclomethasone $400 ;{ }^{\#} \mathrm{p}<0.0001$ vs. $\mathrm{T}_{1}, \mathrm{~T}_{2}, \mathrm{~T}_{4}, \mathrm{~T}_{6} ;{ }^{\wedge} \mathrm{p}=0.018$ vs. $\mathrm{T}_{6} ;{ }^{\wedge} \mathrm{p}=0.001$ vs. $1 \mathrm{~h}, \mathrm{p}<0.0001$ vs. $\mathrm{T}_{1}, \mathrm{~T}_{2}, \mathrm{~T}_{4}, \mathrm{~T}_{6} ;{ }^{\wedge \wedge} \mathrm{p}=0.013$ vs. $\mathrm{T}_{1}, \mathrm{p}=0.003$ vs. $\mathrm{T}_{2}, \mathrm{p}<0.0001$ vs. $\mathrm{T}_{4}, \mathrm{p}=0.003$ vs. $\mathrm{T}_{6}$.

\section{Discussion}

In a previous study [16], we found that natural surfactant combined with beclomethasone decreases pulmonary oxidative stress in preterm lambs with RDS as evidenced by the lower concentration of total hydroperoxide and advanced oxidation protein products in bronchoalveolar lavage fluid of treated animals compared to controls. Neutrophil count in the bronchoalveolar lavage fluid was decreased as well in treated animals.

The results of the present study demonstrate that treatment with natural surfactant combined with beclometh- 
Table 3. Cell counts of bronchoalveolar lavage fluid in the study groups

\begin{tabular}{llllrl}
\hline Treatment & Total cells & Macrophages & Neutrophils & Lymphocytes & Monocytes \\
\hline Surfactant & $19.4 \pm 7.0$ & $4.1 \pm 1.6$ & $4.6 \pm 1.5$ & $5.6 \pm 1.8$ & $4.1 \pm 1.1$ \\
Surfactant + beclomethasone 400 & $14.9 \pm 3.7$ & $4.5 \pm 1.3$ & $2.8 \pm 1.1$ & $4.8 \pm 1.7$ & $2.9 \pm 1.2$ \\
Surfactant + beclomethasone 800 & $11.3 \pm 1.6^{*}$ & $3.6 \pm 1.4$ & $1.8 \pm 0.5^{*}$ & $3.8 \pm 1.6$ & $2.0 \pm 0.9$ \\
\hline
\end{tabular}

${ }^{*} \mathrm{p}<0.05$ vs. surfactant group. Mean values \pm SDs in number of cells $\times 10^{3} / \mathrm{ml}$.

Table 4. Changes in IL- 8 and MIF in preterm lambs treated with surfactant, surfactant plus $400 \mu \mathrm{g} / \mathrm{kg}$ of beclomethasone, or surfactant plus $800 \mu \mathrm{g} / \mathrm{kg}$ of beclomethasone (means \pm SDs)

\begin{tabular}{|c|c|c|c|c|c|}
\hline IL-8 (AU) & Baseline & $\mathrm{T}_{1}$ & $\mathrm{~T}_{2}$ & $\mathrm{~T}_{4}$ & $\mathrm{~T}_{6}$ \\
\hline Surfactant & $0.73 \pm 0.26^{\wedge}$ & $0.76 \pm 0.02$ & $1.7 \pm 0.03$ & $1.86 \pm 0.01$ & $1.85 \pm 0.01$ \\
\hline Surfactant + beclomethasone 400 & $0.71 \pm 0.07^{\wedge \wedge}$ & $0.91 \pm 0.35$ & $1.11 \pm 0.38^{*}$ & $0.92 \pm 0.33^{\#}$ & $1.12 \pm 0.31^{*}$ \\
\hline Surfactant + beclomethasone 800 & $0.70 \pm 0.07^{\wedge \wedge \wedge}$ & $0.68 \pm 0.03$ & $0.82 \pm 0.11^{\#,+}$ & $1.34 \pm 0.37^{\S}$ & $1.12 \pm 0.33^{*}$ \\
\hline MIF, pg/ml & Baseline & $\mathrm{T}_{1}$ & $\mathrm{~T}_{2}$ & $\mathrm{~T}_{4}$ & $\mathrm{~T}_{6}$ \\
\hline Surfactant & $0.41 \pm 0.09$ & $0.73 \pm 0.13^{c}$ & $0.47 \pm 0.05$ & $0.39 \pm 0.07$ & $0.29 \pm 0.10$ \\
\hline Surfactant + beclomethasone 400 & $0.57 \pm 0.29$ & $0.48 \pm 0.12$ & $0.75 \pm 0.52$ & $0.44 \pm 0.05$ & $0.53 \pm 0.32$ \\
\hline Surfactant + beclomethasone 800 & $0.39 \pm 0.08^{\mathrm{cc}}$ & $1.01 \pm 0.48^{\mathrm{D}}$ & $0.90 \pm 0.03^{\mathrm{DD}}$ & $0.98 \pm 0.58^{\mathrm{DDD}}$ & $0.97 \pm 0.37^{\mathrm{DDD}}$ \\
\hline
\end{tabular}

$\mathrm{AU}=$ Arbitrary units. ${ }^{*} \mathrm{p}<0.05$ vs. surfactant; ${ }^{\#} \mathrm{p}<0.0001$ vs. surfactant; ${ }^{\S} \mathrm{p}<0.01$ vs. surfactant; ${ }^{\wedge} \mathrm{p}<0.0001$ vs. $\mathrm{T}_{2}, \mathrm{~T}_{4}, \mathrm{~T}_{6}$; ${ }^{\wedge \wedge} \mathrm{p}<0.05$ vs. $\mathrm{T}_{2}, \mathrm{~T}_{6} ;{ }^{\wedge \wedge \wedge} \mathrm{p}<0.005$ vs. $\mathrm{T}_{4} ;{ }^{+} \mathrm{p}<0.05$ vs. baseline, $\mathrm{T}_{1}, \mathrm{~T}_{6}, \mathrm{p}<0.01$ vs. $\mathrm{T}_{4} ;{ }^{\mathrm{D}} \mathrm{p}<0.05$ vs. surfactant + beclomethasone 400 ; ${ }^{\mathrm{DD}} \mathrm{p}<0.0001$ vs. surfactant, surfactant + beclomethasone $400 ;{ }^{\text {DDD }} \mathrm{p}<0.05$ vs. surfactant, surfactant + beclomethasone $400 .{ }^{\mathrm{c}} \mathrm{p}<$ 0.0001 vs. baseline, $\mathrm{T}_{2}, \mathrm{~T}_{4}, \mathrm{~T}_{6} ;{ }^{\mathrm{cc}} \mathrm{p}<0.05$ vs. $\mathrm{T}_{1}, \mathrm{~T}_{4}, \mathrm{p}<0.0001$ vs. $\mathrm{T}_{2}, \mathrm{p}<0.01$ vs. $\mathrm{T}_{6}$.
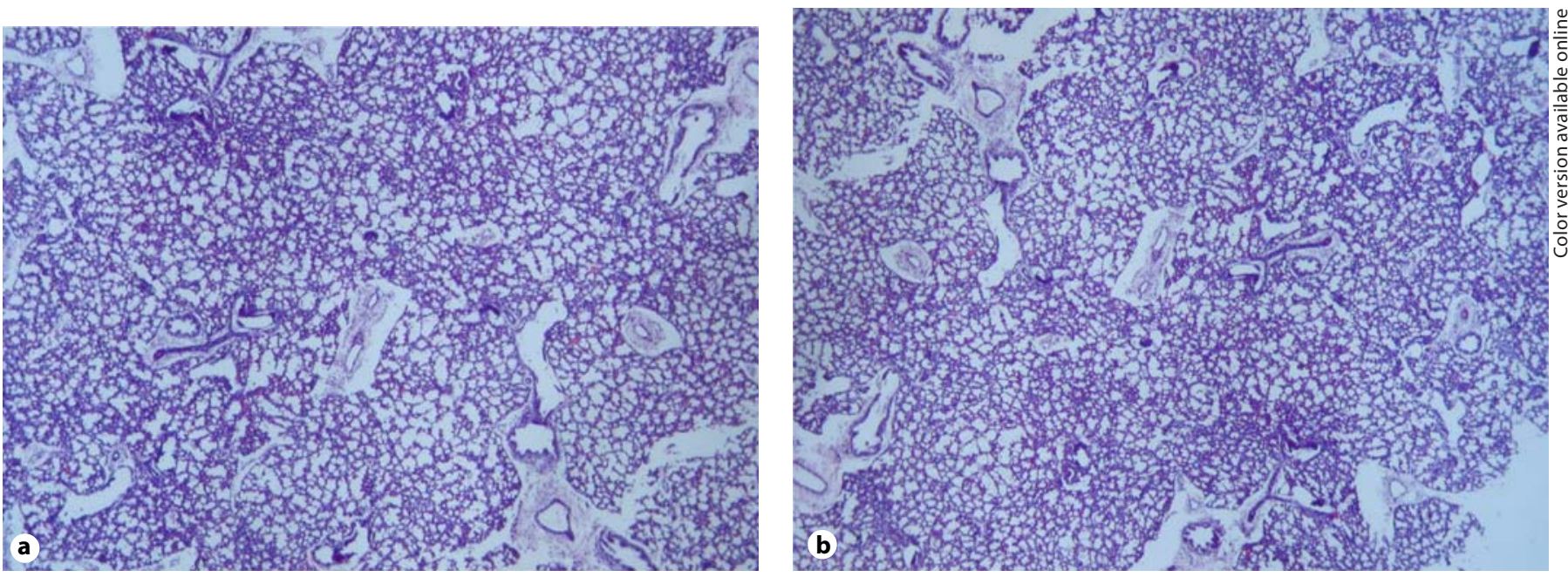

Fig. 1. Photomicrograph of lung sections from preterm lambs treated with surfactant alone (a) or with surfactant plus $800 \mu \mathrm{g} / \mathrm{kg}$ of beclomethasone (b). b Terminal airways appear quite normal; there are rare areas of atelectasis, alveoli of normal size, some interlobular septal leakages and mild inflammatory infiltration of few septa. HE $\times 4$. 
asone is also effective in decreasing IL-8 and in increasing MIF levels in bronchial aspirate samples. Thus, this drug combination is effective in reducing lung inflammation compared with surfactant-only treatment, which supports the hypothesis that the pulmonary antioxidant effects of surfactant plus beclomethasone are associated with downregulation of lung inflammation.

IL- 8 is produced by many leukocyte types as well as fibroblasts, endothelial cells, and epithelial cells in response to other cytokines, bacterial or viral products, and environmental stressors (i.e. reactive oxygen intermediates) [22]. IL-8 strongly attracts neutrophils, and antibodies to IL-8 or its receptor reduce neutrophil influx and lung injury in various experimental models [23]. Therefore, as expected, the IL- 8 concentration is increased in tracheal aspirate of infants who develop BPD [23-25]. It has recently been demonstrated that lipid-rich surfactant preparations can downregulate IL- 8 production by alveolar epithelial cells, thus preventing excessive inflammatory response in alveolar tissues [26]. Interestingly, surfactant does not inhibit the basal release of IL-8 from lung epithelial cells but inhibits its release in response to promoting stimuli such as infection [26]. On the other hand, several studies report that corticosteroids are effective in reducing IL-8 concentration in bronchoalveolar fluid and relieving lung inflammation in preterm infants [2729]. Therefore, our findings that IL- 8 increased in samples from all groups but less so in animals treated with surfactant plus beclomethasone is in agreement with current knowledge since the surfactant did not prevent the increase in IL-8 levels whereas beclomethasone downregulated it.

MIF is an upstream regulator of the innate immune response [30], and has been implicated in the pathogenesis of a number of inflammatory disorders including sepsis, acute RDS (in adults), asthma and inflammatory/ autoimmune diseases [20]. Within the lung, MIF is expressed in bronchial epithelial cells, alveolar macrophages, alveolar endothelium, and in the monocytes and eosinophils isolated by bronchoalveolar lavage [20]. Although its role as a lung anti-inflammatory factor is debated [19], studies in animal models addressing the effect of neutralizing anti-MIF antibodies in endotoxin-induced acute lung injury report that MIF can attenuate pulmonary inflammation [31]. Nonetheless, data from MIF-deficient mice (high mortality, increase in RDS occurrence, decreased lung tissue maturity on histological examination) suggest that decreased MIF is associated with suboptimal lung development. Numerous developmentally regulated promoters of maturation are reduced in the MIF-deficient lung, including vascular endothelial growth factor mRNA and protein, surfactant protein mRNA, and corticosterone [20]. Recently, Kevill et al. [20] using a mouse model of RDS demonstrated the pivotal role for MIF in lung maturation at the developmental stage when human neonates are most susceptible to RDS. They confirmed their results in a cohort of human neonates with RDS showing that higher intrapulmonary MIF levels are associated with a lower likelihood of developing BPD [20]. Thomas et al. [19] reported that MIF is lower in bronchial aspirates of preterm infants with fetal systemic inflammation, reflected by funisitis, than in controls and suggested that this could impair their lung development. Taking these data into account, we think that the increase in MIF induced by the addition of beclomethasone to surfactant in our model can also be beneficial for lung maturation in preterm infants with RDS. Our data confirm that the release of MIF from intracellular pools can be induced by corticosteroids [32], whereas the effect of surfactant on MIF release is still unknown.

With regard to the relationship between neutrophil count and changes of cytokines in bronchoalveolar lavage fluid, we found a positive relationship between the decrease in neutrophil count and IL- 8 concentration and no relationship with the increase in MIF concentration. These data can be explained by the fact that, as mentioned above, IL- 8 is produced by many leukocyte types, such as neutrophils [22], while MIF is mainly produced by bronchial epithelial cells, alveolar macrophages and endothelium, monocytes and eosinophils, whose counts did not vary in our animals [20].

A limitation of our study was that we were not able to measure IL-6. This has also occurred in similar studies and is probably the reason why some authors [33] preferred to assay IL-6 mRNA .

Treatment with surfactant plus $800 \mu \mathrm{g} / \mathrm{kg}$ of beclomethasone consistently improved the lung mechanics of the lambs - confirming the results of previous studies on intratracheal and nebulized inhaled corticosteroids in animal models with lung injuries $[34,35]$ and in infants with BPD [36]. In agreement with Chen et al. [37], animals treated with surfactant plus $800 \mu \mathrm{g} / \mathrm{kg}$ of beclomethasone also displayed decreased neutrophil counts in the bronchoalveolar fluid as further evidence of the antiinflammatory effect of beclomethasone treatment.

Thus, our results demonstrate that the intratracheal administration of surfactant plus $800 \mu \mathrm{g} / \mathrm{kg}$ beclomethasone is effective in decreasing IL-8, increasing MIF concentration and improving lung mechanics in the course of RDS. These effects support the possibility that this 
drug combination might help to reduce the occurrence of BPD in preterm infants through downregulation of lung inflammation and enhanced lung maturation. Nonetheless, since administration of aerosolized corticosteroids to the preterm infant has limited effectiveness in preventing BPD and requires a delivery system which cannot guarantee selective delivery of inhaled steroids to the alveoli [38], their direct intratracheal administration using surfactant as a vehicle may be a suitable way to deliver topical steroids and thus avoid their side effects on cardiovascular function, glycemia, the immune system, and neurodevelopment, while maintaining their favorable effect on lung tissues. On the other hand, Nimmo et al. [39] have previously demonstrated that natural surfactant is an effective vehicle for pulmonary delivery of corticosteroids. The possible absorption of beclomethasone administered through the intratracheal route has not been investigated so far, but data from studies on its intranasal use suggest that the propionate ester of this agent (which was used in our study) is highly lipophilic, and this favors its mucosal absorption and uptake across phospholipid cell membranes with negligible systemic absorption [40]. Moreover, the lack of consistent significant differences in effectiveness between the most commonly used corticosteroids for inhalation supports our choice of administering beclomethasone rather than other steroids [17].

Our study demonstrates that natural porcine surfactant combined with beclomethasone at $800 \mu \mathrm{g} / \mathrm{kg}$ is effective in reducing lung inflammation in an RDS animal model and helps to explain the associated decrease in lung oxidative stress. We found that surfactant plus 800 $\mu \mathrm{g} / \mathrm{kg}$ of beclomethasone increased the MIF level, an important maturative and protective lung factor in preterm infants. These results indicate that large randomized control trials in preterm infants with RDS would help to evaluate the hypothesis that the intratracheal administration of natural surfactant combined with a corticosteroid is effective in decreasing the occurrence of BPD without relevant adverse effects, with particular consideration of the neurodevelopmental outcome.

\section{Acknowledgments}

We want to thank Mr. Giampaolo Chessa of the Veterinary School of the University of Pisa for his contribution in the lamb care; Prof. Mario Arispici of the Veterinary Faculty of the University of Pisa for his technical expertise with the histology studies; Mr. Giusto Bonandrini and Mr. Massimiliano Recenti of Burke \& Burke SpA, Italy, for their generosity in providing mechanical ventilators; Maira Gerakiti and Sean Wattegedera for the production of recombinant ovine cytokines at Moredun Research Institute in conjunction with the BBSRC/RERAD Immunological Toolbox (grant No. BBS/B/00255, MRI/094/04).

\section{Financial Disclosure and Conflicts of Interest}

This study was partially funded by Chiesi Farmaceutici Srl, Parma, Italy. The authors declare that they have no competing interests.

\section{References}

1 Hayes D Jr, Feola DJ, Murphy BS, Shook LA, Ballard HO: Pathogenesis of bronchopulmonary dysplasia. Respiration 2010;79:425436.

-2 Bose CL, Dammann CE, Laughon MM: Bronchopulmonary dysplasia and inflammatory biomarkers in the premature neonate. Arch Dis Child Fetal Neonatal Ed 2008; 93:F455-F461.

-3 Ogden B, Murphy SA, Saunders G, Pathak D, Johnson D: Neonatal lung neutrophils and elastase/proteinase inhibitor imbalance. Am Rev Respir Dis 1984;130:817-821.

4 Groneck P, Gotze-Speer B, Oppermann M, Eiffert H, Speer CP: Association of pulmonary inflammation and increased microvascular permeability during the development of bronchopulmonary dysplasia: a sequential analysis of inflammatory mediators in respiratory fluids of high-risk preterm neonates. Pediatrics 1994;93:712-718.
${ }_{5}$ Horowitz S, Shapiro DL, Finkelstein JN, Notter RH, Johnston CJ, Quible DJ: Changes in gene expression in hyperoxia induced neonatal lung injury. Am J Physiol 1990; 258:L107-L111.

6 Schock BC, Sweet DG, Ennis M, Warner JA, Young IS, Halliday HL: Oxidative stress and increased type-IV collagenase levels in bronchoalveolar lavage fluid from newborn babies. Pediatr Res 2001;50:29-33.

7 Finck CM, Hodell MG, Marx WH, Paskanik AM, McGraw DJ, Lutz CJ, Gatto LA, Picone AL, Nieman GF: Endotoxin-stimulated alveolar macrophage recruitment of neutrophils and modulation with exogenous surfactant. Crit Care Med 1998;26:1414-1418.

$\checkmark 8$ Miles PR, Bowman L, Rao KM, Baatz JE, Huffman L: Pulmonary surfactant inhibits LPS-induced nitric oxide production by alveolar macrophages. Am J Physiol 1999; 276:L186-L196.
\9 Hayakawa H, Giridhar G, Myrvik QN, Kucera L: Pulmonary surfactant phospholipids modulate priming of rabbit alveolar macrophages for oxidative responses. J Leukoc Biol 1992;51:379-385.

10 Kerecman J, Mustafa SB, Vasquez MM, Dixon PS, Castro R: Immunosuppressive properties of surfactant in alveolar macrophage NR8383. Inflamm Res 2008;57:118-125.

-11 Sadowska AM, Klebe B, Germonpre P, De Backer WA: Glucocorticosteroids as antioxidants in treatment of asthma and COPD. New application for an old medication? Steroids 2007;72:1-6.

12 Frank L, Lewis PL, Sosenko IR: Dexamethasone stimulation of fetal rat lung antioxidant enzyme activity in parallel with surfactant stimulation. Pediatrics 1985;75:569-574. 
13 Walther FJ, David-Cu R, Mehta EI, Polk DH, Jobe AH, Ikegami M: Higher lung antioxidant enzyme activity persists after single dose of corticosteroids in preterm lambs. Am J Physiol 1996;271:L187-L191.

14 Chandrasekar I, Eis A, Konduri GG: Betamethasone attenuates oxidant stress in endothelial cells from fetal lambs with persistent pulmonary hypertension. Pediatr Res 2008;63:67-72.

15 Merritt TA, Cochrane CG, Holcomb K, Bohl B, Hallman M, Strayer D, Edwards DK 3rd, Gluck L: Elastase and alpha-1-proteinase inhibitor activity in tracheal aspirates during respiratory distress syndrome. Role of inflammation in the pathogenesis of bronchopulmonary dysplasia. J Clin Invest 1983;72: 656-666.

16 Dani C, Corsini I, Burchielli S, Cangiamila V, Longini M, Paternostro F, Buonocore G, Rubaltelli FF: Natural surfactant combined with beclomethasone decreases oxidative lung injury in the preterm lamb. Pediatr Pulmonol 2009;44:1159-1167.

-17 Main C, Shepherd J, Anderson R, Rogers G, Thompson-Coon J, Liu Z, Hartwell D, Loveman E, Green C, Pitt M, Stein K, Harris P, Frampton GK, Smith M, Takeda A, Price A, Welch K, Somerville M: Systematic review and economic analysis of the comparative effectiveness of different inhaled corticosteroids and their usage with long-acting beta- 2 agonists for the treatment of chronic asthma in children under the age of 12 years. Health Technol Assess 2008;12:1-174.

18 De Dooy JJ, Mahieu LM, van Bever HP: The role of inflammation in the development of chronic lung disease in neonates. Eur J Pediatr 2001;160:457-463.

19 Thomas W, Seidenspinner S, KawczyńskaLeda N, Kramer BW, Chmielnicka-Kopaczyk M, Marx A, Szymankiewicz M, Speer CP: Systemic fetal inflammation and reduced concentrations of macrophage migration inhibitory factor in tracheobronchial aspirate fluid of extremely premature infants. Am J Obstet Gynecol 2008;198:64.e1e6.
0 Kevill KA, Bhandari V, Kettunen M, Leng L, Fan J, Mizue Y, Dzuira JD, Reyes-Mugica M, McDonald CL, Baugh JA, O'Connor CL, Aghai ZH, Donnelly SC, Bazzy-Asaad A, Bucala RJ: A role for macrophage migration inhibitory factor in the neonatal respiratory distress syndrome. J Immunol 2008; 180: 601-608.

21 Ietta F, Todros T, Ticconi C, Piccoli E, Zicari A, Piccione E, Paulesu L: Macrophage migration inhibitory factor in human pregnancy and labor. Am J Reprod Immunol 2002;48: 404-409.

22 Mukaida N: Pathophysiological roles of interleukin-8/CXCL8 in pulmonary diseases. Am J Physiol Lung Cell Mol Physiol 2003; 284:L566-L577.

23 Baier RJ, Loggins J, Kruger TE: Monocyte chemoattractant protein-1 and interleukin-8 are increased in bronchopulmonary dysplasia: relation to isolation of Ureaplasma urealyticum. J Investig Med 2001;49:362-369.

- 24 Vento G, Capoluongo E, Matassa PG, Concolino P, Vendettuoli V, Vaccarella C, Frezza S, Zuppi C, Romagnoli C, Ameglio F: Serum levels of seven cytokines in premature ventilated newborns: correlations with old and new forms of bronchopulmonary dysplasia. Intensive Care Med 2006;32:723-730.

25 Liu DY, Wu J, Zhang XY, Feng ZC: Expression of IL-8, SP-A and TGF-betal in bronchoalveolar lavage fluid of neonates with bronchopulmonary dysplasia. Zhongguo Dang Dai Er Ke Za Zhi 2010;12:444-446.

26 Abate W, Alghaithy AA, Parton J, Jones KP, Jackson SK: Surfactant lipids regulate LPSinduced interleukin-8 production in A549 lung epithelial cells by inhibiting translocation of TLR4 into lipid raft domains. J Lipid Res 2010;51:334-344.

27 Groneck P, Goetze-Speer B, Speer CP: Effects of inhaled beclomethasone compared to systemic dexamethasone on lung inflammation in preterm infants at risk of chronic lung disease. Pediatr Pulmonol 1999;27:383387.

28 Irakam A, Miskolci V, Vancurova I, Davidson D: Dose-related inhibition of proinflammatory cytokine release from neutrophils of the newborn by dexamethasone, betamethasone, and hydrocortisone. Biol Neonate 2002;82:89-95.

29 Schultz C, Rott C, Temming P, Schlenke P, Möller JC, Bucsky P: Enhanced interleukin-6 and interleukin-8 synthesis in term and preterm infants. Pediatr Res 2002;51: 317-322.
0 Calandra T, Roger T: Macrophage migration inhibitory factor: a regulator of innate immunity. Nat Rev Immunol 2003;3:791-800.

- 31 Korsgren M, Källström L, Uller L, Bjerke T, Sundler F, Persson CG, Korsgren O: Role of macrophage migration inhibitory factor (MIF) in allergic and endotoxin-induced airway inflammation in mice. Mediators Inflamm 2000;9:15-23.

32 Baugh JA, Donnelly SC: Macrophage migration inhibitory factor: a neuroendocrine modulator of chronic inflammation. J Endocrinol 2003;179:15-23.

33 Ikegami M, Carter K, Bishop K, Yadav A, Masterjohn E, Brondyk W, Scheule RK, Whitsett JA: Intratracheal recombinant surfactant protein d prevents endotoxin shock in the newborn preterm lamb. Am J Respir Crit Care Med 2006;173:1342-1347.

- 34 Mokra D, Mokry J, Drgova A, Petraskova M, Bulokova J, Calkosvka A: Intratracheally administered corticosteroids improve lung function in meconium-instilled rabbits. Physiol Pharmacol 2007;58:389-398.

35 Wang J, Winskog C, Edston E, Walther SM: Inhaled and intravenous corticosteroids both attenuate chlorine gas-induced lung injury in pigs. Acta Anaesthesiol Scand 2005; 49:183-190.

36 LaForce WR, Brudno DS: Controlled trial of beclomethasone dipropionate by nebulization in oxygen- and ventilator-dependent infants. J Pediatr 1993;122:285-288.

37 Chen CM, Fang CL, Chang CH: Surfactant and corticosteroid effects on lung function in a rat model of acute lung injury. Crit Care Med 2001;29:2169-2175.

38 Shah SS, Ohlsson A, Halliday H, Shah VS: Inhaled versus systemic corticosteroids for preventing chronic lung disease in ventilated very low birth weight neonates. Cochrane Database Syst Rev 2007;17:CD002057.

39 Nimmo AJ, Carstairs JR, Patole SK, Whitehall J, Davidson K, Vink R: Intratracheal administration of glucocorticoids using surfactant as a vehicle. Clin Exp Pharmacol Physiol 2002;29:661-665.

40 Derendorf H, Meltzer EO: Molecular and clinical pharmacology of intranasal corticosteroids: clinical and therapeutic implications. Allergy 2008;63:1292-1300. 